\title{
PENERAPAN IPTEKS PADA DESA TANGGUNTITI DAN TEGALMENGKEB KECAMATAN SELEMADEG TIMUR KABUPATEN TABANAN BALI
}

\author{
I G.P.R. Adi ${ }^{1}$, N.W. Siti ${ }^{2}$, dan I N. Ardika ${ }^{3}$
}

\begin{abstract}
ABSTRAK
Kegiatan Ipteks bagi Wilayah (IbW) Desa Tangguntiti dan Tegalmengkeb, Kecamatan Selemadeg Timur, Kabupaten Tabanan, bertujuan untuk : pengembangan potensi wilayah mengacu RPJM berbasis Ipteks dengan mensinergikan kepakaran perguruan tinggi dan sumberdaya pemerintah daerah serta masyarakat. Luaran yang dihasilkan antara lain : (1) Produk beras sehat (padi organik); (2) badan usaha milik desa (BUMDes); (3) ayam keperluan ritual; (4) pakan silase dan pupuk organik; (5) Jaja tradisional keperluan ritual sebagai produk komersial; (6) Laporan dan publikasi jurnal. Kegiatan meliputi : (1) Alih teknologi cara budidaya padi organik dengan metode System of Rice Intensification (SRI), penanganan panen dan pasca panen (packaging) serta jalinan pemasaran beras sehat dengan BUMD Kabupaten Tabanan; (2) Transfer teknologi fermentasi dalam pembuatan pakan dari limbah pertanian (jerami) untuk persediaan pakan sapi pada musim kemarau, dan pengolahan kotoran dan urine sapi menjadi pupuk organik; (3) Pengembangan ternak ayam buras secara intensif (kandang) dan transfer teknologi breeding untuk menghasilkan ayam upakara (keperluan ritual Hindu Bali); (4) Pengembangan BUMDes sebagai lembaga ekonomi masyarakat melalui peningkatan mutu SDM dan pembentukan unit retail (agromart) yang memasarkan produk masyarakat dan IRT/KUBE; (5) Pengembangan IRT/KUBE pengolahan hasil pertanian (padi dan palawija) menjadi jajan upakara (keperluan ritual Hindu Bali) komersial; dan Publikasi hasil aplikasi Ipteks bagi wilayah melalui seminar, artikel proseding, dan jurnal ilmiah.
\end{abstract}

Kata Kunci : aplikasi Ipteks, bagi wilayah, padi organik, iakan air tawar, hemat air

\begin{abstract}
Activities IbW Desa Tangguntiti and Tegalmengkeb, East Selemadeg District, Tabanan District, aims to: the development of regional potential refers to RPJM based science and technology by synergizing the expertise of universities and local government resources as well as the community. The resulting outputs are: (1) Healthy rice products (organic rice); (2) village-owned enterprises (BUMDes); (3) chicken for ritual purposes; (4) silage feed and organic fertilizer; (5) traditional Jaja ritual purposes as commercial products; (6) Reports and journal publications. Activities include: (1) Transfer of technology of organic rice cultivation method of System of Rice Intensification (SRI), handling of harvest and post-harvest (packaging) and marketing healthy rice with BUMD Tabanan Regency; (2) Transfer of fermentation technology in the manufacture of feed from agricultural waste (straw) for the supply of cattle feed in the dry season, and processing of cow dung and urine into organic fertilizer; (3) Intensive cattle breeding (breeding) and transfer of breeding technology to produce upakara chicken (ritual Hindu Bali); (4) Development of BUMDes as a community economic institution by improving the quality of human resources and the establishment of retail units (agromart) marketing the community products and IRT / KUBE; (5) Development of IRT / KUBE processing of agricultural products (rice and palawija) into traditional commercial Balinese (ritual Hindu
\end{abstract}

${ }^{1}$ Staf Pengajar Fakultas Pertanian Universitas Udayana

${ }^{2}$ Staf Pengajar Fakultas Peternakan Universitas Udayana, wayansiti@unud.ac.id

${ }^{3}$ Staf Pengajar Fakultas Peternakan Universitas Udayana 
ritual) snacks; and Publication of Science and Technology results for the region through seminars, proseding articles, and scientific journals.

Keywords : application of Science, for the region, organic rice, freshwater fish, water saving

\section{PENDAHULUAN}

Kecamatan Selemadeg Timur merupakan salah satu kecamatan dari 10 kecamatan yang ada di Kabupaten Tabanan, berbatasan dengan Kecamatan Selemadeg di sebelah barat, dan Kecamatan Kerambitan di timur, Samudera Indonesia di selatan, dan di sebelah utara berbatasan dengan Kecamatan Penebel. Luas wilayah Kecamatan Selemadeg Timur yaitu 120,15 Km2 dengan mewilayahi 10 Desa Dinas, 72 Dinas Banjar dan 32 Desa Pekraman, dengan jumlah penduduk 21.770 Jiwa terdiri dari 10.852 laki-laki dan 10.918 perempuan sesuai data bulan pebruari 2010 . Desa Tanguntiti dan Desa Tegalmengkeb merupakan dua desa dari 10 desa yang terdapat di Kecamatan Selemadeg Timur, yaitu yaitu : Desa Megati, Desa Bantas, Desa Gadungan, Desa Gunungsalak, Desa Tangguntiti, Tegalmengkeb, Desa Tangguntiti, Desa Beraban, Desa Mambang, dan Desa Gadung Sari. Desa Tegalmengkeb dan 1 luas wilayah masing-masing 12,70 dan 22,49 km2. Jumlah penduduk untuk Desa Tangguntiti sebanyak 3515 dengan komposisi 2249 laki-laki dan 2359 perempuan yang terbagi dalam $1257 \mathrm{KK}$, sedangkan desa tegalmengkeb memiliki jumlah penduduk 4608 jiwa terdiri dari 788 laki-laki dan 774 perempuan dan $446 \mathrm{KK}$.

Penggunaan lahan di wilayah Kecamatan Selemadeg Timur sekarang dipilah menjadi tanah sawah 1.161 Ha, tanah Tegalan/Perkebunan 1.434,0 Ha, tanah pekarangan 616,0 Ha, perkebunan 4.904,0 Ha, kuburan 16,0 Ha tanah lain-lainnya 3.884,0 Ha. Struktur perekonomian di Kecamatan Selemadeg Timur masih sebagian besar mengandalkan hasil pertanian sawah. Disamping hal tersebut, mata pencaharian yang lain ada dari industri kecil, dagang dan buruh bangunan. Sumbar Daya Alam berupa lahan/tanah perkebunan dan sawah yang sangat luas, komoditas yang diusahakan seperti tanaman padi, kelapa, pisang, kakao dan kopi yang terletak di hampir seluruh desa yang ada di kecamatan Selemadeg Timur. Fasiltas pendidikan yang tersedia sudah cukup memadai, di desa Tegalmengkeb terdapat 1 TK dan 1 SD, sementara di Desa Tangguntiti memilik 2 TK, 4 SD dan 1 SMP. Untuk pendidikan menengah atas sudah tersedia di ibu kota kecamatan Selemadeg Timur yang berjarak sekitar $5 \mathrm{~km}$.

Kesehatan menjadi hal penting bagi kehidupan masyarakat, di desa Tangguntiti telah memiliki fasilitas yang memadai yaitu 8 posyandu, 1 puskesmas dan 1 puskesmas pembantu dengan 1 orang dokter umum dan 1 orang bidan. Di tegalmengkeb terdapat 3 posyandu dan 1 puskemasma pembantu dengan 1 orang bidan. Lembaga keuangan masyarakat desa yang tersedia di wilayah tersebut terdiri dari lembaga perkreditan desa (LPD) yaitu sebanyak 1 LPD di Desa Tegalmengkeb dan 1 LPD di Desa tangguntiti.. Lembaga keuangan lain seperti Bank BRI dan BPD terdapat di kota Kecamatan selemadeg Timur berjarak $5 \mathrm{~km}$ dari kedua desa tersebut yang sangat mudah diakses oleh masyarakt. Untuk membangun perekonomian masyarakat di setiap desa dibentuk Badan Usaha Milik Desa (BUMDes) yang menjadi pemerintah desa. BUMDes tersebut menampung berbagai produk ekonomi masyarakat untuk selanjutnya dipasarkan secara bersamasama melalui badan usaha tersebut.

\section{METODE PELAKSANAAN}

Untuk mensolusikan berbagai persoalan prioritas yang telah disepakai di wilayah $\mathrm{I}_{\mathrm{b}} \mathrm{W}$ dilakukan melalui beberapa pendekatan, yaitu: (1) Model analisis kebutuhan, yaitu kegiatan yang dilakukan sesuai dengan kebutuhan masyarakat; (2) Model Partisipatory Rural Appraisal (PRA), yaitu dengan melibatkan masyarakat dalam berbagai aspek mulai dari perencanaan, pelaksanaaan hingga

\section{2 | BULETIN UDAYANA MENGABDI}


evaluasi; (3) model Entrepreneurship Capacity Building (ECB), yaitu meningkatkan kapasitas masyarakat berwirausaha; (4) model Teknologi Transfer (TT), yaitu aplikasi teknologi tepat guna; dan (5) model Informasi Teknologi (IT), yaitu memanfaatkan teknologi informasi dalam pemasaran.

\section{HASIL DAN PEMBAHASAN}

Kegiatan yang sudah dilaksanakan pada realisasi program IbW di Desa Tangguntiti dan Tegalmengkeb tahun 2017 meliputi 6 kegiatan yaitu :

\section{Sosialisasi kegiatan IbW kepada Bappeda, Instansi terkait, dan masyarakat sasaran}

a) Sosialisasi ke Bappeda Tabanan

Sosialisasi dilaksanakan di kantor Bappeda Tabanan pada tanggal 26 April 2017 yang dihadiri oleh sekretaris Bappeda dan instansi terkait (Bapeluh, PU, Dinas pertanian, penyuluh lapangan, dan team $\mathrm{IbW}$ ). Kegiatan ini bertujuan untuk koordinasi dan sinkronisasi program IbW dengan pemda Tabanan agar tidak terjadi tumpang tindih dalam pelaksanaannya di lapangan. Beberapa program yang disepakati untuk tahun 2017 antara lain : 1) Pengembangan KUBE Jajan keperluan ritual (upakara); 2) Pengembangan KUBE pengrajin ornamen penjor; 3) Penguatan kelembagaan BUMDES; 4) Aplikasi teknik breeding dalam usaha ternak ayam buras untuk keperluan ritual (upakara); dan 5) peningkatan pendapatan petani swah melalui usaha penangkaran benih jagung tahan kering. Program IbW ini disambut baik oleh pemda Tabanan karena sangat mendukung program yang akan menjadikan Tabanan sebagai "gerbang pangan"

b) Sosialisasi ke Desa Tanguntiti dan Desa Tegalmengkeb

Sosialisasi program IbW tahun 2017 kepada masyarakat Desa Tanguntiti dan Desa Tegalmengkeb dilaksanakan dalam satu hari karena lokasinya berdekatan yaitu pada tanggal 5 Mei 2017. Kegiatan dilaksanakan di kantor desa setempat yang dihadiri oleh kepala desa, sekretaris desa, kepala dusun, dan team $\mathrm{IbW}$. Dalam pertemuan tersebut dibicarakan mengenai program yang akan dikerjakan dalam tahun 2017 sesuai dengan RPJM pemda kabupaten Tabanan. Dari hasil pembicaraan tersebut disepakati empat program utama, yaitu : 1) Pengembangan KUBE Jajan keperluan ritual (upakara); 2) Pengembangan KUBE pengrajin ornamen penjor; 3) Penguatan kelembagaan BUMDES; 4) Aplikasi teknik breeding dalam usaha ternak ayam buras untuk keperluan ritual (upakara); dan 5) peningkatan pendapatan petani swah melalui usaha penangkaran benih jagung tahan kering. Disepakati pula untuk melaksanakan kegiatan penyuluhan/pelatihan pembuatan pupuk dan pestisida organik untuk menambah pengetahuan masyarakat karena selama ini mereka membuat pupuk secara otodidak dan masih secara alami (belum kena sentuhan teknologi). Sosialisasi juga dilakukan dengan petani setempat sebagai pelaksana program yang akan dikerjakan. Lokasi kegiatan disepakati di Dusun Batanbuah, Desa Tangguntiti dan sebagai pelaksana lapangan adalah kelompok ternak "karya Winangun" yang dipimpin oleh Bapak I Wayan Sukasuci.

\section{Peningkatan pendapatan petani sawah (subak) melalui penangkaran benih jagung lahan kering}

Persoalan utama petani di wilayah ini adalah ketersediaan air irigasi yang sangat kurang, sementara petani hanya menggantungkan hidup dari pertanian padi. Pada tahun 2017, awal pelaksanaan IbW pertanian padi terserang hama tikus dan penyakit sundep yang menyebabkan gagal panen. Program yang dikembangkan adalh melalui usaha penangkar benih jagung varietas tahan kering. Jenis jagung ini merupakan hasil pengembangan dari Fakultas Pertanian Universitas Udayana dan sangat 
laku di pasaran karena cocok dikembangkan pada lahan yang kekurangan air termasuk di wilayah IbW. Kegiatan penangkaran benih dilakukan di subak Aseman 4. Pada lahan demplot seluas 30 are. Usaha ini mampu meningkatkan pendapatan petani hingga 2 kali lipat.
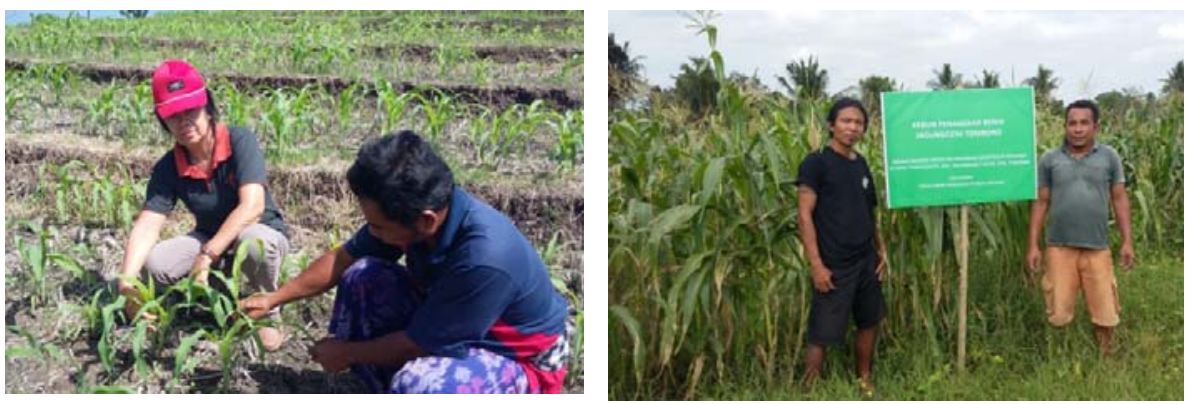

Gambar 1. Penangkaran benih jagung lahan kering

\section{Usaha peternakan ayam keperluan ritual melalui aplikasi teknik breeding}

Kegiatan dilakukan pada kelompok ternak karya winangun Desa tangguntiti, beranggotakan 20 orang. Kegiatan dimulai tanggal 4 Mei 2017 dengan melakukan penjajagan kepada anggota kelompok. Dilanjutkan dengan penyuluhan dan pelatihan cara vaksin, teknik perkawinan sadok, dan cara penetasan. Instruktur atau pelatih berasal dari Universitas Udayana yaitu : I Made Wirapartha, SPt, Msi memberikan tentang cara pemberian vaksin, Ir. I Nyoman Ardika, Msi memberikan tentang teknik breeding untuk menghasilkan ayam upakara, dan Dr. Ir. Ni Made Sucisukmawati memberikan pemberian pakan. Selain itu juga dilakukan pembuatan demplot budidaya ayam buras istem jaring serta pemberian insentif berupa 100 ekor induk dan 20 ekor pejantan. Selain itu juga diserahkan 4 buah alat penetasan dan 14 set jaring.
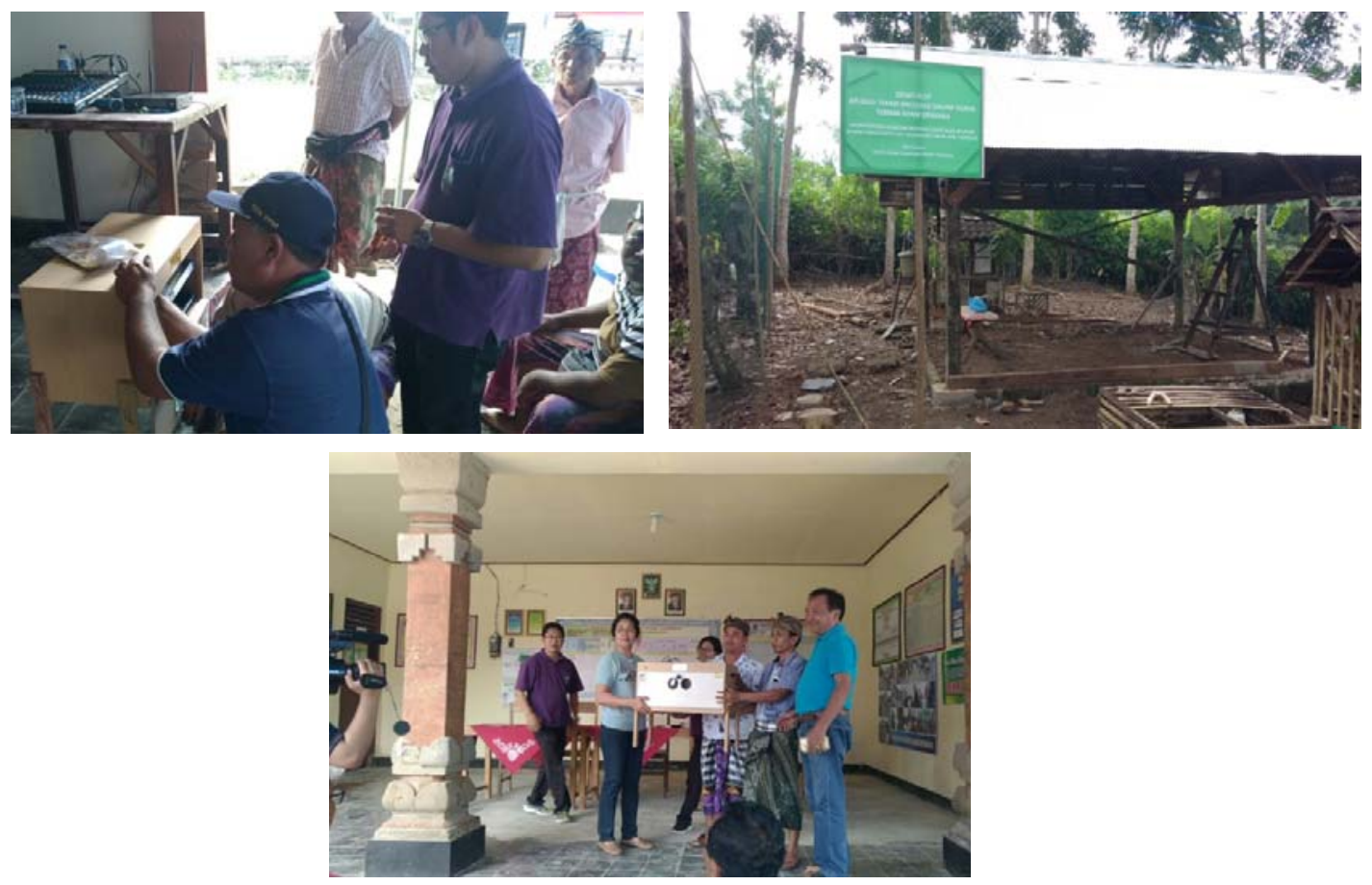

Gambar 2. Peternakan ayam keperluan ritual melalui aplikasi teknik breeding 


\section{Pengembangan BUMDES melalui peningkatan kapasitas SDM pengelola}

Badan usaha milik desa merupakan nadi perekonomian dan sember keuangan masyarakat desa. Pengembangan BUMDES dilakukan melalui pelatihan SDM pengelola, dilakukan pada tanggal 8 Agustus 2017 bertempat di kantor BUMDES diikuti oleh 10 orang pengelola dengan menghadirkan 2 orang instruktur yaitu : Ir. I Made Arthana, MM dari Bapelitbangda Kabupaten Tabanan dan Ni Ketut Seminari, SE, Msi dari Staf dosen Fakultas Ekonomi Universitas Udayana Denpasar.

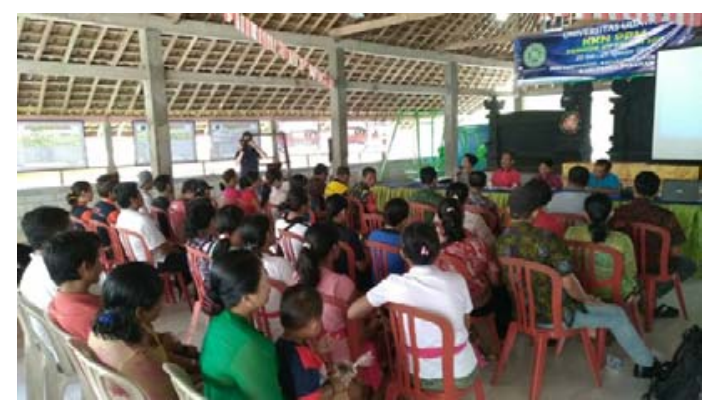

Gambar 3. Pengembangan BUMDES

\section{Pengembangan KUBE ornamen penjor}

Kegiatan dilaksanakan pada tanggal 8 agustus 2017 bertempat di Dusun Jakatebel Desa Tangguntiti diikuti oleh 30 orang ibu-ibu anggota PKK. Instruktur/pelatih berasal dari Institut Seni Indonesia yaitu Drs. I Made Radiawan, M.Erg. dibantu oleh 2 orang asisten pelatih. Materi yaang dilatihkan terdiri dari cara membuat ornamen Bali perlengkapan penjor yang terbuat dari ibung. Hasil kegiatan menunjukkan bahwa para peserta secara umum telah terampil membuat ornamen penjor yang dilatihkan. Ornamen penjor produk masyarakat selanjutnya akan dipasarkan melalui BUMDES.

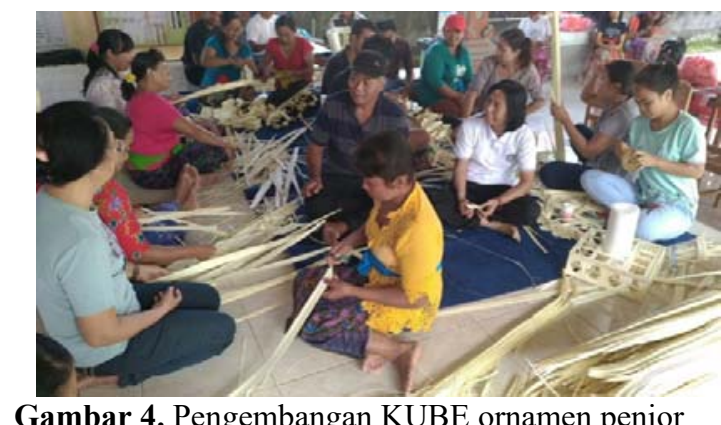

Gambar 4. Pengembangan KUBE ornamen penjor

\section{Pengembangan KUBE Jajanan untuk keperluan acara adat}

Pelatihan KUBE jajanan untuk keperluan acara adat dilakukan pada tanggal 8 Agustus 2017 bertempat di Dusun Kebon Desa Tangguntiti melibatkan 30 orang ibu-ibu anggota PKK. Pelatih berasal dari Universitas Diyana Pura Denpasar yaitu Bapak. Drs Eko dibantu oleh 2 orang asisten pelatih. Pada kegiatan ini hibahkan 1 set peralatan pengolahan jajanan untuk keperluan acara adat kepada peserta. 


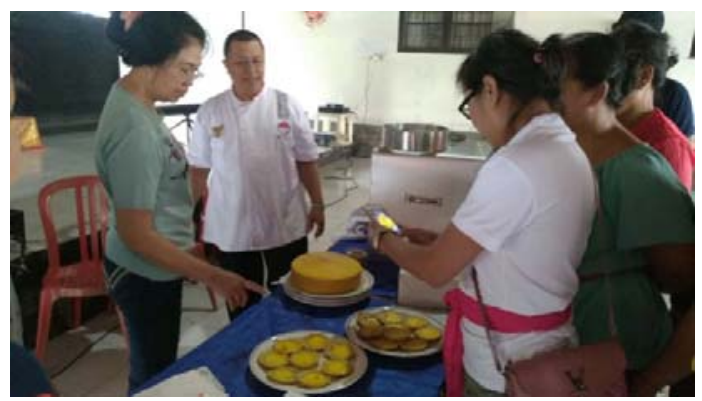

Gambar 5. Pengembangan KUBE Jajanan

\section{Pelatihan pengolahan limbah pertanian (jerami) menjadi pakan ternak (sapi) dan pengolahan limbah ternak menjadi pupuk untuk tanaman.}

Kegiatan pelatihan dilakukan di Desa Tegalmengkeb, diikuti oleh sebanyak 40 peternak sapi. Materi yang diberikan meliputi teknik fermentasi dalam pembuatan silase dari jerami padi dan pengolahan kotoran sapi menjadi pupuk organik yang berkualitas dengan memanfaatkan mikroba efektif. Pelatihan diberikan oleh A.A. Nyoman Wijana seorang praktisi yang sudah sangat berhasil dalam mengembangkan teknologi ini. Pada kegiatan pelatihan ini diberikan sebanyak 40 botol (kemasan 5 liter) mikroba efektif kepada peserta untuk diaplikasikan secara mandiri di rumah masing-masing.

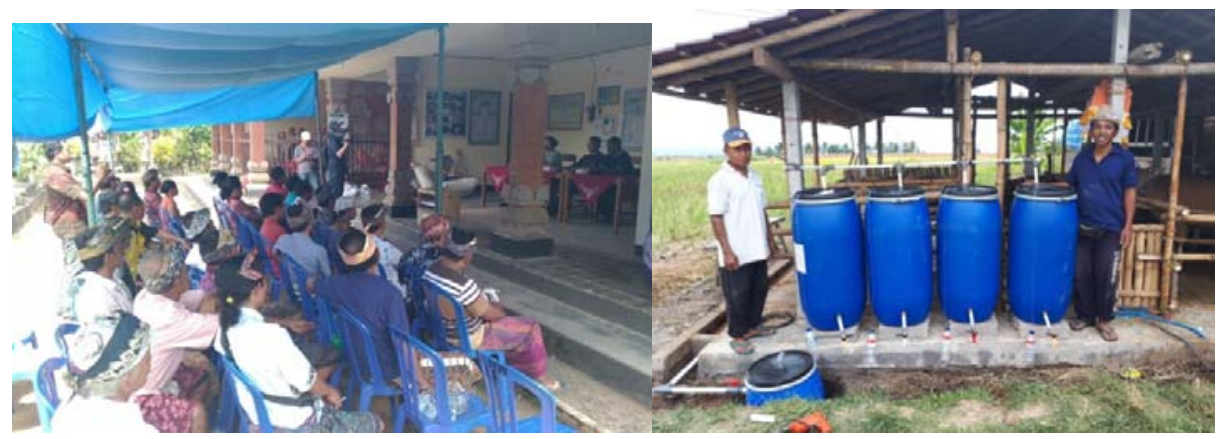

Gambar 6. Pelatihan pembuatan silase dan biourine

\section{Budidaya ikan air tawar hemat air}

Kegiatan pengembangan budidaya ikan air tawar hemat air meliputi kegiatan pelatihan dan pembuatan demplot. Pelatihan dilakukan pada tanggal 27 September 2017 diikuti oleh masyarakat yang tertarik dengan usaha budidaya ikan air tawar. Budidaya ikan air tawar hemat air menerapkan sistem kolam sirkulasi semi tertutup yaitu, budidaya ikan tidak dilakukan pada air mengalir tetapi pada kolam terpal dengan pengairan tetap. Kebutuhan oksigen air disuplai melalui airator yang hidup selama 24 jam, setiap 1 minggu air dikurangi sebanyak $20 \%$ dari volume kolam, selanjutnya diisi dengan air baru dari bak penampungan air. Air yang tersimpan pada kolam penampungan air merupakan hasil penjernihan dari air buangan kolam sebelumnya. 


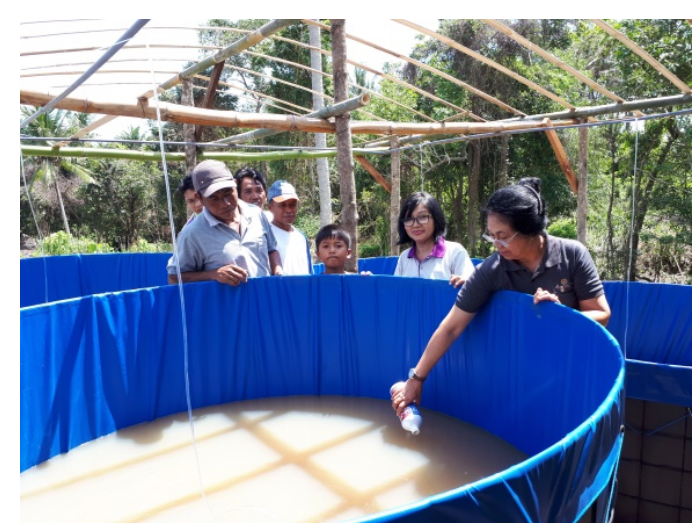

Gambar 6. Budidaya ikan air tawar hemat air

\section{KESIMPULAN DAN SARAN}

Berdasarkan kegiatan seperti tersebut di atas maka dapat disimpulkan beberapa hal yaitu sebagai berikut :

1. Sosialisasi dengan intansi terkait telah dilakukan dengan hasil program $\mathrm{IbW}$ akan disinergikan dengan program Pemda setempat.

2. Kegiatan yang telah berhasil dilaksanakan yaitu : 1) aplikasi teknologi fermentasi dalam pengolahan limbah pertanian menjadi pakan ternak dan pengolahan pupuk dari kotoran ternak; 2) penangkaran benih jagung tahan kering; 3) aplikasi teknik breeding untuk menghasilkan ayam keperluan ritual; 3) Peningkatan kapasitas SDM BUMDES; 4) Pengembangan KUBE jajanan untuk keperluan acara adat; 5) Pengembangan KUBE ornamen penjor, dan 6) Budidaya ikan air tawar hemat air.

3. Kegiatan yang akan dilakukan sebagai tindak lanjut berupa pendampingan serta aplikasi sistem SRI dan pertanian organik untuk produksi beras sehat.

4. Kegiatan IbW mendapatkan respon yang sangat baik dari masyarakat karena sesuai dengan kebutuhan masyarakat.

\section{UCAPAN TERIMA KASIH}

Penulis mengucapkan terima kasih kepada KEMENRISTEK DIKTI atas dana yang diberikan lewat program IbW, Rektor Universitas Udayana, Ketua LPPM beserta staf terima kasih atas tenaga yang diberikan dalam pelaksanaan di lapangan, sehingga pengabdian kepada masyarakat terlaksana sesuai rencana.

\section{DAFTAR PUSTAKA}

Badan Pusat Statistik (BPS). 2015. Kecamatan Selemadeg Timur dalam Angka tahun 2015. Badan Pusat Statistik Kabupaten Tabanan.

Anon. 2015. Profil Pebangunan Desa Tangguntiti, Kecamatan Selemadeg Timur Kabupaten Tabanan. Anon. 2015. Profil Pebangunan Desa Tegalmengkeb, Kecamatan Selemadeg Timur Kabupaten Tabanan. 